\title{
Editorial
}

\section{Innovation and Technology to Shake up Psychological Science}

\author{
Lisiane Bizarro \\ Universidade Federal do Rio Grande do Sul \\ Sebastião Almeida \\ Universidade de São Paulo \\ Alcyr Oliveira \\ Universidade Federal de Ciências da Saúde de Porto Alegre
}

Psychology is a science essential to the evolution of technology, engineering, and mathematics (Breckler, 2010). Nevertheless, technology and innovation have not had an easy link with psychology worldwide and it is no different in Brazil. This special issue of Trends in Psychology Temas em Psicologia, is not a thorough review on this subject, but a small and biased sample of innovation and technology in Brazilian psychology.

Psychology connects with other sciences. As new technologies emerge, psychology both borrows from other sciences' theories and methods and enriches other sciences with theories and methods (Breckler, 2013). On the other hand, the public understanding of psychologists and of psychology has not matched the potential of this science (Weber, Pavei, \& Biscaia, 2005) since the last century (Leme, Bussab \& Otta, 1989). Psychology is not included in the science curriculum at school, even though knowledge of the subject could help people to live better. Not surprisingly, funding opportunities are unlikely to consider psychology as a technological discipline because not knowing the science of psychology undermines its growth as a discipline and as a profession (Beckler, 2013; Falcão, 2013). The American Psychological Association sets out to increase recognition of psychology as a science as a main goal of its strategic plan (APA, 2009) and to enhance psychology's prominence as a core discipline in science, technology, engineering and mathematics (Breckler, 2010).

In order to promote awareness, understanding, and ultimately funding for our research, researchers and psychologists must be aware that the discipline of psychology is innovative and technological. The proposal for this special issue was born inside the working group on Psychobiology, Neuroscience and Behavior of the Associação Nacional de Pesquisa e Pós Graduação em Psicologia [National Association of Research and Postgraduate Study in Psychology] (ANPEPP). The aim was to trigger and expand this debate to other areas in psychology.

In 2012 the group participated in the II Encontro Nacional de Processos Psicológicos Básicos [Second National Meeting of Basic Psychological Processes] (ENPPB), a satellite meeting of ANPEPP symposium, where a seminar on science and technology was organized by Alcyr Oliveira (ENPPB, 2012). In this seminar, Dora Ventura, Sebastião Almeida and Rochelle Fonseca suggested strategies to increase visibility, funding, and interdisciplinary innovative research, following national and international trends. Technology and innovation are present in Brazilian psychology, but we should show how it has being incorporated. We need first to understand and define technology and innovation and identify it in our fields and efforts. This lack of comprehension prevents research psychologists (and graduate students) from competing for national and international funding opportunities and a wide range of collaborative work.

In the last two years the importance of innovation and technology has become even clearer. Brazil has a leading role among the Latin American countries and is one of the powerful forces of scientific advancement. The contribution of psychology to this growth is remarkable. Paradoxically, it does not translate into innovative practices on health or educational issues that abound in professional practice. Psychologists would like to have quick access to new scientific information and to be able to analyze, 
interpret critically, and translate it into their practice. Therefore, psychologists (and other professionals) should help in this process.

The application of scientific evidence is more efficient and ethical than common sense or theoretical derivatives when approaching any problem. In psychology, this application will eventually develop and disseminate into practice. Innovation and technology is not equivalent to applied research or basic research or a product of research, but they need to become a competency. In a forward-looking world of science, psychology is front and center because unraveling and understanding cognition, emotion, and behavior are among the greatest frontiers of science (Breckler, 2010). Scientific organizations, undergraduate and graduate courses must promote awareness and advocate for the contribution of psychology to technology and innovation to keep Brazilian psychological sciences competitive worldwide.

In the following pages, researchers will present studies on the development of technology and the application of new technologies that required an effort to state why they are examples of innovation and technology. Still, it might be difficult to understand how to define innovation and technology in psychology from these examples. They show gaps that must be quickly overcome so that Brazilian psychology takes its place within the competitive context. One of these gaps is the rare collaboration between groups of researchers in our continental-size country. Another gap is the timid use of multidisciplinary convergent methodologies to assess the same construct or problem, mainly due to the diversity of subjects and interests of the research groups. The increasing number of independent researchers in our country will help to reduce these gaps in the future, but they could be maximized if undergraduate and graduate education encompass innovation and technology as a transversal competency to be acquired. Therefore, it is important to incorporate innovation and technology with lectures, supervisions, research projects and debates inside our groups. Both future funding and social needs will demand evidence-based, tailormade interventions applied to different populations and problems, as well as methods to assess both evidence and effectiveness of interventions in health, education, work, and social environments. This demand will, however, only be put on psychology professionals if researchers are aware of this potential and communicate how to combine output with other sciences on solving complex problems. This will be an opportunity to challenge our theories and current orthodox teaching of future psychologists and independent researchers. Moreover, this requires changing our own working environment. It has been said that innovative fields and interdisciplinary research are constrained by inertia and conservatism of departments and disciplines. Our current social sciences departments (which include psychology) need to match their institutional structures to meet today's intellectual challenges (Christakis, 2013). This special issue offers an invitation to shake up our psychological science.

\section{References}

American Psychological Association [APA]. (2009). American Psychological Association Strategic Plan. Retrieved November 2, 2014 from http://apa.org/about/apa/strategic-plan/default.aspx

Breckler, S. J. (2010). Sustaining the status quo. [Electronic version] Monitor on Psychology, 41(11), 40. Retrieved November 2, 2014, from http://www.apa.org/monitor/2010/12/sd.aspx

Breckler, S. J. (2013). Stronger STEMs. Monitor on Psychology, 44(8), 32. Retrieved November 2, 2014, from http://www.apa.org/monitor/2013/09/sd.aspx

Christakis, N. A. (2013, July 19). Let's shake up the social sciences. [Electronic version] New York Times Sunday Review. Retrieved November 02, 2014, from http://www.nytimes.com/2013/07/21/opinion/sunday/ lets-shake-up-the-social-sciences.html

Encontro Nacional de Processos Psicológicos Básicos [ENPPB II] (2012). Relato. Retrieved November 2, 2014, from https://sites.google.com/site/enppbii/relato

Falcão, J. (2013). O Ciência sem Fronteiras e a Psicologia. Boletim da ANPEPP 40. 30 de janeiro. Retrieved November 2, 2014, from http://www.anpepp.org.br/conteudo/view?ID_CONTEUDO=53

Leme, M. A. V. S., Bussab, V. S., \& Otta, E. (1989). A representação social da Psicologia e do psicólogo. Psicologia: Ciência e Profissão, 9(1), 29-35., http://dx.doi.org/10.1590/S1414-98931989000100009. Retrieved November 02, 2014.

Weber, L. N. D., Pavei, C. A., \& Biscaia, P. (2005). Imagem social do psicólogo e da psicologia para a população de Curitiba: 12 anos depois. Psicologia Argumento, 23(40), 19-30. 